\title{
In vitro Evaluation of Trichoderma Species for the Biological Control of Beauveria bassiana (Balls) Vuill Causing White Muscardine Disease of Silk Worm, Bombyx mori L. under Temperate Conditions
}

\author{
Haroon Rashid Ahmad* and Gulzar Ahmad
}

Central Sericultural Research and Training Institute Pampore, Post bag 88 GPO Srinagar 190001(Jammu \& Kashmir UT), India

*Corresponding author

\section{Keywords}

Bombyx mori L, White muscardine, Beauveria bassiana, Antagonism, Trichoderma spp.

Article Info

\section{Accepted:}

10 March 2020

Available Online:

10 April 2020

\section{A B S T R A C T}

\begin{abstract}
Antagonistic potentiality of four isolates of Trichoderma species viz. Trichoderma viride isolate A, Trichoderma viride isolate $\mathrm{M}$, Trichoderma harzianum isolate $\mathrm{C}$ and Trichoderma harzianum isolate $\mathrm{L}$ against Beauveria bassiana causing white muscardine disease of Silk worm, Bombyx mori L, was studied invitro by studying the mycelial interaction between them as well as by the effect of culture filtrate of biocontrol agents on sporulation and spore germination of pathogen. Trichoderma viride isolate $\mathrm{A}$ and Trichoderma viride isolate $M$ produced the maximum inhibition zone of 68.00 and 44.25 $\mathrm{mm}$ area respectively, followed by Trichoderma harzianum isolate $\mathrm{L}$ with inhibition zone of $39.60 \mathrm{~mm}$ and Trichoderma harzianum isolate $\mathrm{C}$ with $33.50 \mathrm{~mm}$. In dual culture all the isolates of Trichoderma spp. over grew the pathogen and covered the entire medium surface. Its mycelia coiled around the hyphae of test pathogen and finally disintegrated it. The inhibition in mycelial growth by the cultural filtrate of Trichoderma harzianum isolate L was $55.35 \%$. The cultural filtrate of Trichoderma viride isolate A has inhibited the spore production and germination by 63.65 and $83.70 \%$ respectively. The mechanism of antagonism was found to be hyper parasitism and antibiosis. The studies conducted revealed that all the tested biocontrol agents possessed antagonistic properties against Beauveria bassiana in vitro and could be used in controlling the white muscardine disease of silkworm.
\end{abstract}

\section{Introduction}

Mulberry Silkworm, Bombyx mori L is most susceptible to different diseases caused by various infecting pathogens viz., viruses, fungi, bacteria and microsporodians. The white muscardine disease caused by a pathogen Beauveria bassiana (Balls) vuill an entomopathogenic fungi is prevalent in all the Sericulture countries of the world (Bulmer and fromtling, 1983). The cocoon production losses by this disease in different countries varies from 5-50\% (Jayaramaiah et al., 1986; Jayaramaiah and kuberappa, 1987) and is among the most common diseases of silkworm in India (Krishna swami, 
1973).During 1920-1925 the entire sericulture industry in Italy and France was wiped out due to this disease (Govindan et al., 1998)

In J\&K state as well the outbreak of this disease caused the heavy loss to the silk industry every year (Chishti and Sahaf, 1989). Many successful attempts have been made to save the crop loss of silkworm Bombyx mori, L by application of chemicals and fungicides (Kawakami, 1973; Samson and Mummigutti, 1979; Samson et al., 1986; Baig et al., 1987; Balavenkatasubbaiah et al., 1994; Pasha and Alam, 1999;Govindan et al., 1998; Munshi et al., 2004; Haroon et al., 2002) However, farmers are reluctant to use these disinfectants directly on silkworms mainly because of their apprehension about their toxicity on silkworms or at least adverse effects on the health of worms and quality of cocoons formed.

This has focussed the attention of sericulturists on the use of an eco-friendly method through the use of biological agents for sustainable silkworm disease management. Thus in the present investigation four locally available isolates of Trichoderma spp. Viz Trichoderma viride isolate A, Trichoderma viride isolate $\mathrm{M}$, Trichoderma harzianum isolate $\mathrm{L}$ and Trichoderma harzianum isolate $\mathrm{C}$ have been used invitro for their antagonistic effect on mycelia growth, sporulation and spore germination of Beauveria bassiana causing white muscardine disease of Silkworm, Bombyx mori L.

\section{Materials and Methods}

\section{Isolation of causal organism}

The pathogenic fungi (Beauveria bassiana) were isolated repeatedly from the dead cadavers of muscardine diseased silkworm which were collected from rearer's houses.
The freshly dead and mummified worms were surface sterilized with 0.1 percent Mercuric chloride solution for about 5 minutes and later rinsed with sterilized distilled water several times (Johnston and Booth, 1983). The cuticular tissue of the dead worms was then cut into 4mm square bits (Kirlay et al., 1974) with the help of sterilized scalp/blade. These bits were again passed through 0.1 percent solution of Mercuric chloride for 30 seconds. Finally with the help of sterilized inoculation needle these bits were placed under aseptic conditions on the petriplates containing Samsinakova,s Corn Liqu1or Agar (SKLAM) media (Samsinakova,1966) and incubated at $28+-2^{0} \mathrm{C}$ and $85+-5 \%$ relative humidity for about 10 days.

\section{Isolation of antagonist (biocontrol)}

All the isolates of the biocontrol agents viz., Trichoderma viride isolate-A, Trichoderma viride isolate-M, Trichoderma harzianum isolate- $\mathrm{L}$ and Trichoderma harzianum isolate -C were procured from Division of Pathology, S.K University of Agricultural sciences and technology Shalimar Kashmir $(\mathrm{J} \& \mathrm{~K})$. They were grown on Peptone yeast agar medium.

Interaction between biocontrol agent and pathogen (Beauveria bassiana) was studied by Agar plug and Dual culture methods and by the effect of Culture filtrate of biocontrol agents on pathogen growth and spore production.

\section{Agar plug method}

In agar plug method spore suspension of pathogen (Beauveria bassiana) was poured in sterilized $90 \mathrm{~mm}$ petriplates containing PDA medium. The seeded plates were then stored in refrigerator at $4^{\circ} \mathrm{C}$ and used as and when required. A $7 \mathrm{~mm}$ disc of biocontrol grown on Peptone yeast extract medium was kept at the 
centre of seeded plates and Incubated at 28+$2^{0} \mathrm{C}$ for 4days (Munshi et al., 2004).

Diameter of the inhibition zone produced by biocontrol agents against pathogen was measured as clear distance between periphery of agar plug and growth of the Pathogen (Shivapratap et al., 1996).

\section{Dual culture method}

In dual culture method $7 \mathrm{~mm}$ plug of the test pathogen and biocontrol agent were placed 70 $\mathrm{mm}$ apart from each other on $90 \mathrm{~mm}$ petridish. Whole set was incubated at $28+\ldots{ }^{\circ}$ Cfor 15 days. The method described by Bell et al., (1982) was used to test the antagonistic ability of biocontrol against the pathogen Beauveria bassiana.

\section{Effect of cultural filtrate (metabolite) of bio control agents on pathogen growth}

Metabolites of the bio control agents were obtained by growing them separately in peptone yeast extract liquid medium for 15 days and filtering the culture filtrate through Whatman filter paper No.42 and repeated centrifugation at 9000rpm (Shivaparatap, 1996). Pathogen (Beauveria bassiana) was grown on samsinakova agar medium amended with $20 \%$ metabolite of biocontrol agent. The pathogen in medium without metabolite served as control. Each treatment and control was replicated five times. Growth of the fungus in both the sets were measured after 15 days of incubation and compared.

\section{Effect of metabolites on spore production and germination}

$7 \mathrm{~mm}$ mycelial disc of pathogen was cut from above experiment at different places in each treatment and macerated thoroughly in $20 \mathrm{ml}$ sterilized distilled water to release the spores. The average number of Spores per $\mathrm{ml}$ spore suspension per microscopic field (x600) was counted from 20 observations in treated and control set to determine the inhibition in spore production.

The effect of metabolites on spore germination of the pathogen was studied by the hanging drop method (Brian, 1960). The percentage inhibition in mycelia growth, spore production and spore germination were calculated by the formula of Vincent (1947).

\section{Statistical analysis}

Each experiment was performed twice with five replications with appropriate control batch. All the data was statistically analysis.

\section{Results and Discussion}

\section{Interaction between bio control agents and Beauveria bassiana}

\section{Agar plug method}

All the four isolates of Trichoderma spp. tested viz T.viride isolate-A, T. viride isolate$\mathrm{M}$, T.harzianum isolate-L and T. harzianum isolate-C (Table 1) produced the inhibition zone ranging from 33.50 to $68.00 \mathrm{~mm}$ against B.bassiana. Maximum inhibition zone $(68.00 \mathrm{~mm})$ was produced by $T$. viride isolate A followed by T.viride isolate -M (44.25 $\mathrm{mm})$. T.harzianum isolate -L and T.harzianum isolate-C were also effective by producing an inhibition zoon of 39.60 and $33.50 \mathrm{~mm}$ respectively (plate-2 a-d).

\section{Dual culture method}

All the biocontrol agents used in the present study showed strong antagonism against the pathogen by covering the entire medium surface and completely overgrowing the pathogen and were grouped into class-1(plate 3 a-d). 
Effect of culture filtrate (metabolites) on mycelia growth of B.bassiana

Metabolites of all the biocontrol agents inhibited the growth of pathogen in varying degree. Maximum inhibition was produced by culture filtrate of T.harzianum isolate-L $(55.35 \%)$ followed by that of T.harzianum isolate-C (54.28\%) and T.viride isolate-A (53.48\%). Minimum inhibition zone was produced by T.viride isolate-M (50.00). However, they were statistically different from each other.

\section{Effect of metabolites on spore production and germination}

The metabolites of all bio-control agents have reduced the spore production and germination of the test pathogen (Table 2). The percentage decrease in spore production over control varied from 54.49 to $63.65 \%$.T.viride isolateA have produced the maximum reduction $(63.65 \%)$ followed by T.viride isolate-M $(61.70 \%)$ and T.harzianum isolate-L
(55.03\%).Minimum inhibition (54.49\%) was recorded in T.harzianum isolate $-\mathrm{C}$. The inhibition in spore germination ranged from 73.78 to $83.70 \%$ with T.viride isolate -A produced the maximum inhibition $(83.70 \%)$ followed by T.viride isolate-M $(81.80 \%)$.Minimum inhibition in spore germination $(73.78 \%)$ was recorded in T.harzianum isolate-C.

Thus from the above study it was observed that all the isolates of Trichoderma spp. viz. Trichoderma viride isolate-A, Trichoderma viride isolate-M, Trichoderma harzianum Isolate-L and Trichoderma harzianum isolate$\mathrm{C}$ evaluated under invitro conditions have inhibited the mycelia growth, sporulation and spore germination of the pathogen, Beauveria bassiana. Trichoderma viride isolate-A and $\mathrm{M}$ proved highly antagonistic followed by Trichoderma harzianum isolate -Land C against the tested pathogen. These antagonists have suppressed the growth of Beauveria bassiana by way of Mycelial interaction and as well as metabolite.

Table.1 Interaction between biocontrol agents and Beauveria bassiana in Agar plug, Dual culture and culture filtrate methods

\begin{tabular}{|c|c|c|c|c|}
\hline \multicolumn{5}{|c|}{ Method } \\
\hline \multirow[t]{2}{*}{ Biocontrol agent } & \multirow{2}{*}{\begin{tabular}{|l}
\multicolumn{1}{|c}{ Agar Plug } \\
$\begin{array}{l}\text { Mean area } \\
\text { of inhibition } \\
\text { zone(mm) }\end{array}$
\end{tabular}} & \multirow{2}{*}{\begin{tabular}{l}
\multicolumn{1}{c}{ Dual } \\
Culture \\
Class
\end{tabular}} & \multicolumn{2}{|c|}{ Culture filtrate } \\
\hline & & & $\begin{array}{c}\text { Colony } \\
\text { diameter }(\mathbf{m m})\end{array}$ & $\begin{array}{l}\% \text { inhibition } \\
\text { over control }\end{array}$ \\
\hline Trichoderma viride isolate-A & $68.00 \mathrm{a}$ & 1 & $5.21 \mathrm{c}$ & $53.48(46.99)$ \\
\hline Trichoderma viride isolate-M & $44.25 b$ & 1 & $5.60 \mathrm{~d}$ & $50.00(45.00)$ \\
\hline Trichoderma harzianum isolate-L & $39.60 \mathrm{c}$ & 1 & $5.00 \mathrm{a}$ & $55.35(48.07)$ \\
\hline Trichoderma harzianum isolate-C & $33.50 \mathrm{~d}$ & 1 & $5.12 b$ & $54.28(47.45)$ \\
\hline Control(/untreated) & - & & $11.20 \mathrm{e}$ & - \\
\hline $\mathrm{CDP}=(0.05)$ & 1.28 & & 0.01 & \\
\hline
\end{tabular}

Figures with in parenthesis are angular transformation values.

Means followed by similar letters are statistically identical 
Table.2 Effect of culture filtrates of bio-control agents on spore production and spore germination of $B$. bassiana

\begin{tabular}{|l|l|l|l|l|}
\hline \multicolumn{1}{|c|}{ Culture filtrate } & \multicolumn{2}{|c|}{ Spore production } & \multicolumn{2}{l|}{ Spore germination } \\
\cline { 2 - 5 } & $\begin{array}{l}\text { No of spores } \\
\text { per }\end{array}$ & $\begin{array}{l}\text { \% Inhibition } \\
\text { over control }\end{array}$ & $\begin{array}{l}\text { \% Spore } \\
\text { germination }\end{array}$ & $\begin{array}{l}\text { \% Inhibition } \\
\text { over control }\end{array}$ \\
\hline Trichoderma viride isolate-A & $14.00 \mathrm{a}$ & $63.65(52.92)$ & $16.30(23.81) \mathrm{a}$ & $83.70(66.18)$ \\
\hline Trichoderma viride isolate-M & $14.75 \mathrm{a}$ & $61.70(51.76)$ & $18.20(25.25) \mathrm{b}$ & $81.80(64.74)$ \\
\hline Trichoderma harzianum isolate-L & $17.32 \mathrm{~b}$ & $55.03(47.88)$ & $22.12(28.05) \mathrm{c}$ & $77.88(61.94)$ \\
\hline Trichoderma harzianum isolate-C & $17.53 \mathrm{~b}$ & $54.49(47.57)$ & $26.22(30.80) \mathrm{d}$ & $73.78(59.19)$ \\
\hline Control/untreated) & $38.52 \mathrm{c}$ & - & $100.00(90.00) \mathrm{e}$ & - \\
\hline cDP=(0.05) & 1.17 & & 0.21 & \\
\hline Figund & & & \\
\hline
\end{tabular}

Figures with in parenthesis are angular transformation values.

Means followed by similar letters are statistically identical
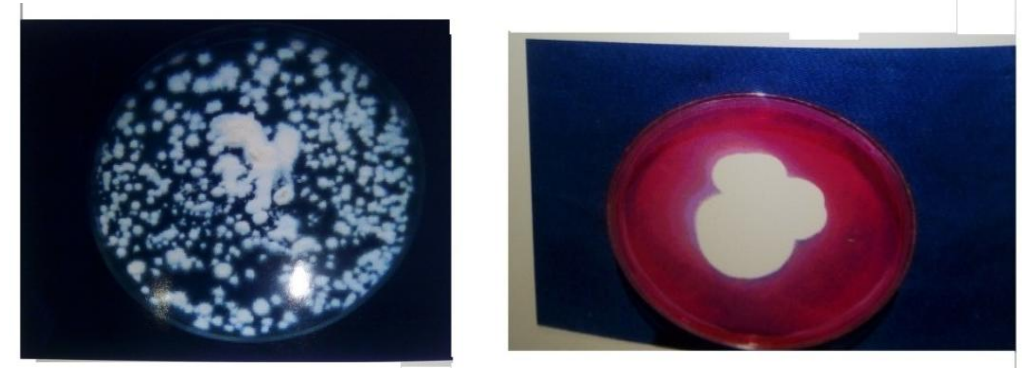

Plate.1 Isolation and growth of Beauveria bassiana in

(a) Samsinakova's corn Liquor Agar Medium and(b) PDA medium

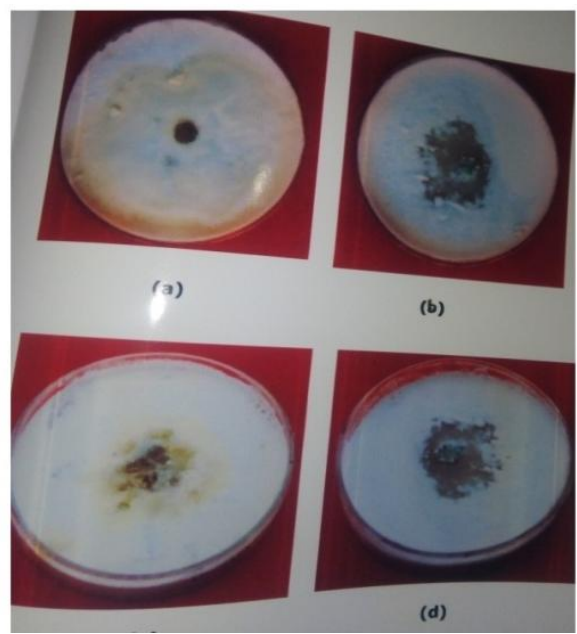

Plate.2 Mycelial interaction by Agar plug method

(Inhibition Zone produced by bio control agent against Beauveria bassiana)
a) T.viride-A
b) T.viride-M
c) T.harzianum-L d) T.harzianum-C 


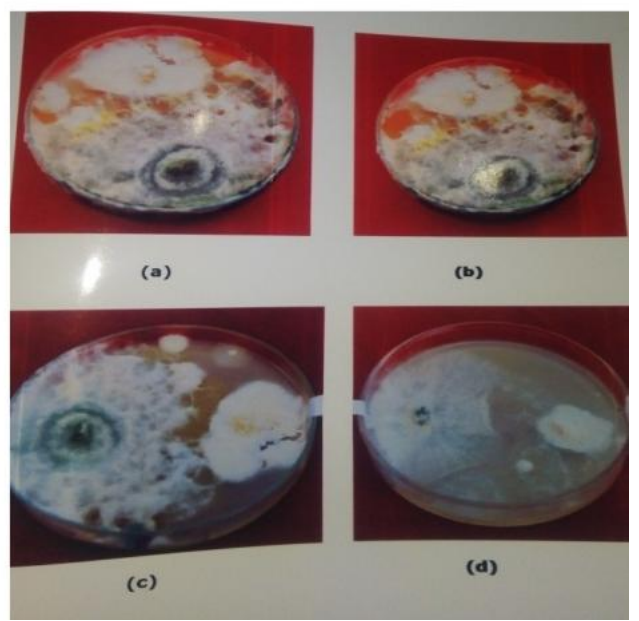

Plate.3 Mycelial interaction by dual culture method
a) T.viride-A and Beauveria bassiana b)
b) T.viride-M and Beauveria bassiana.
c) T. harzianum-L and Beauveria bassiana d) T.harzianum-C and Beauveria bassiana

This type of activity of Trichoderma spp. was previously reported against many plant pathogens (Chet et al., 1979; Bell et al., 1982; Elade et al., 1983; Sivan et al., 1984; Goodman and Burpee, 1991; Shivapratap et al., 1996; Charati et al., 1998; Biswas and Sen, 2000; Sridhar et al., 2000; Munshi and Dar, 2004)

Since antagonists have inhibited the growth of pathogen at mycelia as well as metabolite level, the strong antagonistic action of above biocontrol agents in the present study is attributed due to the production of antimicrobial metabolites as well as by hyper parasitism.

Thus the results of the present study have shown that all the isolates of Trichoderma species possesses antagonistic properties against the Beauveria bassiana causing white muscardine disease in silkworm, Bombyx mori L, and could be used as efficient bio control agent for the management of this menace. However, further studies regarding their field efficacy and bioassay on silkworms should be carried out to find out their field applicability.

\section{References}

Bulmer, G. S, Fromtling R. A.1983 Pathogenic mechanism of Mycotic Agents.In: Fungi pathogenic for humans and animals.D.Howard(ED), Marcel Dekker, New York, p.32

Baig, M. And Kumar, P.1987. Appropriate Sericulture Techniques. (ED)Manjeet, S. Jolly, CSR\&TI Mysore PP.123-127

Balavenkata subbaiah, M; Nataraj, B., Baig, M. and Datta, R.K. 1994. Comparative efficacy of different disinfectants against Nuclear Polyhedrosis Virus and Beauveria bassiana of Sikworm, Bombyx mori L an Journal of Sericulture. 33:142-145

Bell, D.K., Wells, H.D. and Morkhans, C.R. 1982. In vitro antagonism of Trichoderma Species against six fungal pathogens. Phytopathology 72:379-382.

Brain P.W. 1960. Griseotulvin.Trans. Br. Mycology SOC, 43:1-13.

Biswas, R.K. and Sen.C.2000. Identification of effective isolates of Trichoderma harzianum Rifai for biocontrol of Macrophomina phaseolina. Journal of Mycology and plant pathologh.30:408-410

Chet, I., Hadar, M.Y., Elade, Y., Katan, J. and Henis, M.Y.1979. Biological control of soil born Plant pathogens by Trichoderma harzianum 585-591. In: B. Schippers and W. Gams (Eds). Soil born plant pathogens. 
Academic press, London.

Chishti, M.Z. and Sohaf, K.A. 1989. Studies on Fugal diseases of silkworm, Bombyx mori L. in Kashmir. Journal of Entomological Research 13:72-75.

Charati, S.N., Mali, J.B. and Pawar, N.B.1998. Bio Control of fusarium Wilt of Cotton by Trichoderma Spp. J. Maharashtra Agriculture University, 23:304-305.

Kirlay, Z., Klemt, Z., Solymosy, F and Voros, J.1974 Methods in plant pathology with special reference to breeding for disease resistance. Elsevier Scientific Publishing Company, Amsterdam London. pp509.

Munshi, N.A.and Dar, G.H.2004. Invitro evaluation of some locally isolated micro fungi for antagonism against mulberry Fusarial blight pathogen. Sericologia, 44:341346.

Pasha, M.K. and Alam, M.S.1999. Bulletin of sericulture research 1:87-89.

Samson, M.V., Baig, M., Sapru, M.L.and Narsimhana, M.N.1986. Efficacy of certain fungicides and disinfectants for the control of white muscardine disease in mulberry Silkworm. Indian Journal of Sericulture. 25:78-83.

Samson, M.V. and Mummigutti, S.G. 1979. In vitro screening of chemicals against Beauveria bassiana (Bals) vuillemin. Indian Journal of Sericulture.18:48-50.

Elade, Y., Chet, I., Boyle, P. and Henis, Y. 1983. Parasitism of Trichoderma Spp. On Rhizoctonia solani and Sclerotium rolfsi. Scanning Electron Microscopy and Florescence microscopy. Phytopothology, 73:418-422.

Goodman, D.M.and Burpee, L.1991. Biological Control of dollar spot diseases of creeping bentgrass. Phytopathology, 70:119-121.

Govindan, R., Narayanaswamy, T.K. and Devaih, M.C. 1998. Principles of Silkworm pathology. Seri Scientific publishers, Bangalore, India, pp.239-256.
Haroon Rashid, Zeya, S.B., Khan, M.A. and Mir, M.R. 2002. Eficacy of different bed disinfectants against incidence and spread of diseases' in Sikworm Bombyx mori L. under field conditions .Oriental Sciensis, 7: 115-120.

Jayaramaiah, M., Kuberappa, G.C., Devaiah, M.C and Kotikal, Y.K. 1986. White muscardine disease of silkworm and its management. Indian Silk, pp.15-16.

Jayaramaiah, M. and Kuberappa, G.C. 1987. Silkworm mycosis. No.48, University of Agriculture Sciences, Bangalore, p.85.

Johnston, A. and Booth, C. 1983. Plant pathologist pocket Book. Common Wealth Mycological Institute Kew Survey, England, pp.439.

Krishnaswamy, S., Narsimhana, M,N., Suryanarayana, S.K. and Kumarraj, S. 1973. Manual on Sericulture. Vol.2. Silkworm Rearing FAO. Rome, p. 131.

Kawakami, K.1973. Effect of organo sulphurous Fungicides by dusting to silkworm body on control of fungus disease of the silkworm. Sensi-Kenk (Acta Sericologia), 90:404-409.

Samsinakova, A. 1966. Growth and sporulation of submerged cultures of the Fungus Beauveria bassiana on various media. J. Invertebr. Path. 8: 395-400.

Sivan, A.Y., Elad. and Chet, M.I. 1984. Effect of Fungal antagonists on growth of Chick pea plants and wilt caused.by Fusarium oxysporium Plant diseases research.12:103107.

Shivapratap, H.R., Tomy Philip and Sharma, D.D. 1996. In vitro antagonism of Trichoderma species against mulberry leaf spot pathogen, Sercospora moricola. Indian Journal of Sericuture, 35:107-110.

Sridhar, R; Subramanian, A. and Chandramohan, N. 2000. Management of mulberry root rot with antagonistic micro-organisms. Sericologia, 40:383-386.

Vincent, J.M. 1927. Distortion of fungal hyphae in presence of certain inhibitors. Nature.

\section{How to cite this article:}

Haroon Rashid Ahmad and Gulzar Ahmad. 2020. In vitro Evaluation of Trichoderma Species for the Biological Control of Beauveria bassiana (Balls) Vuill Causing White Muscardine Disease of Silk Worm, Bombyx mori L. under Temperate Conditions. Int.J.Curr.Microbiol.App.Sci. 9(04): 945-951. doi: https://doi.org/10.20546/ijcmas.2020.904.113 